\title{
THE INFLUENCE OF RETURN ON EQUITY, COMPANY SIZE, AND INSTITUTIONAL OWNERSHIP ON COMPANY VALUE
}

\author{
Jara Hardiyanti Jalih \\ ITB Ahmad Dahlan Jakarta
}

Article DOI: https://doi.org/10.36713/epra9545

DOI No: 10.36713/epra9545

\begin{abstract}
This research aims to examine the effect of return on equity, firm size, and institutional ownership on firm value. The population in this study is manufacturing companies listed on the Indonesia Stock Exchange (IDX) for the 2019-2021 period. Based on the purposive sampling method there are 148 final samples from this study. The analytical method used is statistical analysis in the form of multiple linear regression tests.

The results of this study indicate that Return On Equity (ROE), and Firm Size have a significant positive effect on Firm Value, whereas Institutional Ownership does not have a significant effect on Firm Value.

KEYWORDS: Return on Equity, Firm Size, Institutional Ownership, and Firm Value
\end{abstract}

\section{INTRODUCTION}

The value of the company always gets special attention from investors and the public, they consider the value of the company to be one of the keys to the company's success

Now the value of the company can give a positive signal to the reaction of investors, especially if the value of a company always increases every year. With an increase in a company's profits and maximizing the value of the company itself, it becomes the company's goal where these things are interrelated which will ultimately improve the welfare of existing shareholders, thus this goal is important for the company to carry out its business continuity. The value of the company can be reflected by the share price of the company

\section{LITERATURE REVIEW}

Signaling Theory

Brigham and Housten (2011) argue that signals or cues are actions taken by companies to provide clues to investors regarding what the company's prospects are like.

Some companies sometimes give positive signals by increasing the company's debt itself, by increasing debt indirectly The health and sustainability of the company can be trusted by several parties, one of which is the creditor. Credit giving companies certainly don't dare to take big risks by providing debt without knowing and being sure of what the company's sustainability will be like in the future

\section{The value of the company}

The wrong price is a reflection of the value of a company, of course, the stock price is not only influenced by the company's performance, but several factors can influence it, such as the condition of the country, one of which is. For example, in 2020, there was a covid-19 pandemic where it indirectly had a very large impact on the company, which would impact stock prices and company performance.

Husnan (2014) stated that the value of the company is the price that is assessed and able to be paid by the prospective buyer when the company is sold, in other words, the value of the company is the estimated price given by the person or prospective buyer if the company is sold.

Suwardika and Mustanda (2017) themselves state that if a company has a good value, this will be reflected in its share price so that the relationship between company value and share price is directly proportional. 


$$
P B V=\frac{\text { Price per share }}{\text { Book value per share }}
$$

\section{Return on Equity (ROE)}

Henry (2017) provides an explanation where Return On Equity is a ratio that can show how much the company's equity contributes in generating net income per year. Investors tend to look at ROE in choosing investments because they are considered companies that have good ROE can provide a good level of profit as well in the future.

Company profitability is the main attraction of a company because profitability is the result obtained through the efforts made by management in its operations on the return of funds invested by shareholders. Investors will receive the profit which is usually paid in the form of dividends either in cash or stock dividends where the dividend will increase the shares owned by the investor.

\section{Company Size}

$$
R O E=\frac{\text { Net profit }}{\text { Total Equity }}
$$

A company can be seen in size by showing total assets, total sales, total profits, tax expenses, and others. Dewi and Sudiartha (2017) state that company size is a description of the size of a company that can be reflected through the total assets owned by a company. Based on the above statement it can be said that the size of the company can be measured by total assets, stock market prices, and others. In addition, the size of the company can also be seen through the total sales and average sales of a company.
Usually, large company size and a company that is expected to be able to continue to grow in the future can describe the level of future profits, this can affect investors' views on the value of the company so that it becomes good information and signal for investors (Putra and Lestari, 2017).

\section{Company Size $=($ Ln $)$ Total Asset \\ Institutional Ownership}

Institutional ownership is the amount of share ownership by institutions, the institutions themselves can be like the government, foreign companies, financial institutions such as insurance, banks, and pension funds contained in the company (Jalestiana, 2018).

Institutions themselves are usually able to control the majority of shares, this is because they have greater resources than other shareholders. The ownership structure, in this case, is institutional ownership in the monitoring role of management, institutional ownership is the most influential party in decision making because of its nature as the majority shareholder, besides ownership institutional is the party that gives control over the management in the company's financial policies. Institutional ownership is the percentage of shares owned by institutions (Pasaribu, et al 2016)

$$
I N S T=\frac{\text { Institutional shareholding }}{\text { Total company shares }}
$$

Figure 2.1.

Frame of Thought

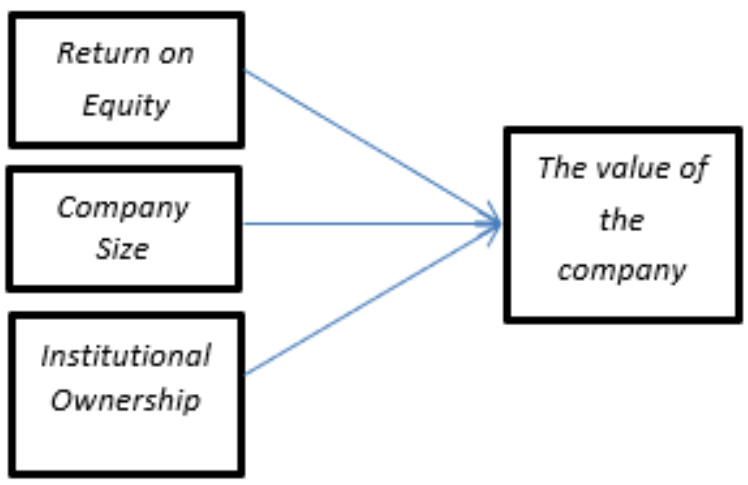

\section{The Effect of Return On Equity (ROE) on Firm Value \\ Profitability as measured by Return On Equity} (ROE) is able to show the efficiency and effectiveness of the use of company assets, where this ratio measures the company's ability to generate profits based on the use of existing equity. With the effectiveness of existing equity management, you will get savings and have sufficient funds to run your business. That is, 
companies that are able to generate good profits will have a positive impact on firm value.

\section{The Effect of Firm Size (Size) on Firm Value}

The size of the company has several categories ranging from small, medium, and large scale. Companies that have a large scale basically have more total company assets than companies with a small scale so that companies with a large scale tend to have accounting policies that reduce profits, the smaller the profit the smaller the resources issued by the company. It concludes that firm size has an effect on firm value.

\section{The Effect of Institutional Ownership on Firm Value}

The value of the company will increase along with the increase in company productivity. Increased productivity of the company can be seen from the ability of management to generate high profits so that it becomes a positive signal for the market and will increase stock prices. To reduce agency costs that arise in the relationship between managers and owners, the level of institutional ownership is increased with the hope that every management decision will always be controlled and in accordance with the wishes of the owner. With an increase in institutional ownership, it will encourage management to improve its performance so that it will have a positive impact on firm value.
H1 : Return on Equity (ROE) has an effect on Firm Value

H2 : Firm Size has an effect on Firm Value

H3 : Institutional Ownership Affects Firm Value

\section{RESEARCH METHODS}

Population and Research Sample

The population in this study are manufacturing companies listed on the Indonesia Stock Exchange for the 2019-2021 period. Sampling was done by purposive sampling. The data testing technique uses multiple regression. For members of the population who do not meet the requirements, are not selected as research samples.

\section{Data collection technique}

Documentation, namely the collection of available data on the object of research, in this case in the form of financial statement documents of manufacturing companies listed on the Indonesia Stock Exchange for the 2019-2021 period which are downloaded from the http://www.idx.co.id/ website and related company websites .

\section{Hypothesis testing}

Hypothesis testing aims to predict the magnitude of the effect of the dependent variable (dependent variable) by using the independent variable (independent variable). The estimation of the regression equation is as follows:

\section{HYPOTHESIS}

$\begin{array}{lll}\text { PBV }=\beta_{0}+\beta_{1} \text { ROE }+\beta_{2} \text { SIZE }+\beta_{3} \text { INST }+ \text { e } \\ \text { Description: } & : & \text { Price to Book Value } \\ \text { PBV } & : & \text { Constanta } \\ \text { B }_{0} & : & \text { Regression coefficient on each variable } \\ \beta_{1}, \beta_{2}, \beta_{3} \ldots \beta_{8} & : & \text { error } \\ \varepsilon & : & \text { Return On Equity } \\ \text { ROE } & : & \text { Size } \\ \text { SIZE } & : & \text { Institutional Ownership }\end{array}$

\section{DISCUSSION}

\section{Effect of Return on Equity (ROE) on Firm Value}

In this study, Return on Equity (ROE) has a positive effect on firm value (PBV). The results of this study indicate that the size of the ROE value in the company affects the value of the company. The higher the ROE value obtained by the company indicates the company is able to manage its equity optimally so that it can increase company profits which have a good impact on company value.

\section{The Effect of Firm Size (SIZE) on Firm Value}

In this study, firm size (size) has a positive effect on firm value (PBV). The results of this study indicate that the larger the size of the company, the easier it is for the company to obtain funding that can be used to achieve company goals. The size of the company is large and continues to grow illustrates the level of future profits so that. 


\section{The Effect of Institutional Ownership (INST) on Firm Value}

In this study, institutional ownership has no effect on firm value (PBV). The results of the study indicate that the size of the share ownership owned by the institution contained in the company is not able to be a benchmark for the value of the company. In general, institutional ownership plays a role in monitoring the company.

\section{CONCLUSION}

This study aims to find empirical evidence about research on the effect of Return on Equity, Firm Size, and Institutional Ownership on Firm Value (PBV). From the results of data research and discussion carried out, the following conclusions are obtained:

\section{Return on Equity has an effect on Company Value}

The higher the ROE value obtained by the company indicates the company is able to manage its equity optimally so that it can increase company profits which have a good impact on company value.

\section{Firm Size has an effect on Firm Value}

The larger the size of the company, the easier it is for the company to obtain funding that can be used to achieve company goals.

\section{Institutional Ownership has no effect on Company Value}

The size of the share ownership owned by the institution contained in the company is not able to be a benchmark for the value of the company.

\section{SUGGESTION}

The suggestions from the research to be conveyed are as follows:

1. For the company management, always evaluate the company's performance and optimize the use of the company's resources as well as possible so that the company's goals can be realized.

2. In this study, there are still many shortcomings of the test variables which are considered very few, it is hoped that further research can use and add variables in research testing.

3. For further researchers, it is better if the research period used in the study is carried out longer with the latest data updates and is expected to use samples from the company sector so that this research can be generalized to all companies in Indonesia.

\section{BIBLIOGRAPHY}

1. Akerlof, George A. The Market For "Lemons": Quality Uncertainty And The Market Mechanism. The Quarterly Journal Of Economics, Vol. 84, No. 3 (Aug. 1970), Pp. 488-500.

2. Aritonang R., L. R. (2007). Riset pemasaran.Teori dan praktik. Jakarta: Ghalia Indonesia

3. Brigham, Eugene F. Dan Houston, Joel F. 2011. Dasar-Dasar Manajemen Keuangan Terjemahan. Edisi 10. Jakarta: Salemba Empat. Cetakan Pertama, PT. Elex Media Komputindo, Jakarta, PT. Gramedia,

4. Damouri, D. Khanagha, J.B., and Kaffash, M. (2013). The relationship between changes in the financial leverage and the values of the Tehran listed firms. Journal of Financial Management, 3(3), 198-210

5. Dewi, Dewa Ayu Intan Yoga Maha Dan Gede Mertha Sudiartha (2017). Pengaruh Profitabilitas, Ukuran Perusahaan, Dan Pertumbuhan Aset Terhadap Struktur Modal Dan Nilai Perusahaan. E-Jurnal Manajemen Unud, Vol. 6, No. 4, 2017: 2222-2252

6. E-Jurnal Manajemen Unud, Vol. 6, No. 3, 2017: 1248-1277

7. Ghozali, Imam. 2017. Aplikasi Analisis Multivariete Dengan Program IBM SPSS 23 (Edisi 8). Cetakan ke VIII. Semarang : Badan Penerbit Universitas Diponegoro.

8. Gibson, H. C. (2013). Financial statement analysis, 13th edition. Norwalk: South-Western.

9. Godfrey, J., Hodgson, A., Tarca, A., Hamilton, J., and Holmes, S. (2010). Accounting theory, 7th edition. Milton: John Wiley \& Sons Australia, Ltd.

10. Horne, V.and Wachowicz.(2008). Fundamentals of financial management. London: Prentice-Hall Hariyanto, Marina Suzuki Dan Putu Vivi Lestari. Pengaruh Struktur Kepemilikan, IOS, Dan ROE Terhadap Nilai Perusahaan Food And Beverages. E-Jurnal Manajemen Unud, Vol. 4. No. 4. 2015:1599:1626.

11. Haryadi, Etnis. Pengaruh Size perusahaan, Keputusan Pendanaan, Profitabilitas Dan Keputusan Investasi Terhadap Nilai Perusahaan. Jurnal Akuntansi. Vol. 3 No. 2. Juli 2016

12. Hery, 2017. Teori Akuntansi, Pendekatan Konsep Dan Analisis. Grasindo, Jakarta.

13. Husnan, Suad. 2014. Manajemen Keuangan Teori Dan Penerapan (Keputusan Jangka Panjang). Edisi Keempat. Yogyakarta: Bpfe Jakarta.

14. Jalestiana, Renanda. 2018. Pengaruh Kepemilikan Manajerial Dan Institusional Terhadap Nilai Perusahaan Dengan Kebijakan Hutang Sebagai Variabel Moderasi.

15. Mahdaleta, E., Iskandar, M., and Gusnardi, M. N. (2016). Effects of capital structure and profitability on corporate value with company size as the moderating variable of manufacturing companies listed on indonesia stock exchange. Academic Journal of Economic Studies, 2(3), 30-43. 
16. Pasaribu, Dkk. 2016. Pengaruh Struktur Modal, Struktur Kepemilikan Dan Profitabilitas Terhadap Nilai Perusahaan. Jurnal Administrasi Bisnis (Jab)|Vol. 35 No. 1 Juni 2016

17. Purnama, H. (2016). Pengaruh profitabilitas, kebijakan hutang, kebijakan deviden, dan keputusan investasi terhadap nilai perusahaan. Jurnal Akuntansi, 4(1), 11-21.

18. Putra, AA Ngurah Dharma Adi Dan Putu Vivi Lestari. Pengaruh Kebijakan Dividen, Likuiditas, Profitabilitas Dan Ukuran Perusahaan Terhadap Nilai Perusahaan. E-Jurnal Manajemen Unud, Vol. 5, No.7, 2016: $4044-4070$

19. Samosir, Hendrik Es. 2017. Pengaruh Profitabilitas Dan Kebijakan Utang Terhadap Nilai Perusahaan. Journal Bussiness Studies. Vol. 2. No. 1. Hal. 7583. Fakultas Ekonomi Universitas Hkbp Nomensen

20. Santoso, Singgih.2010. Statistik Parametik, Konsep dan Aplikasi dengan SPSS. Suwardika, dan Mustanda. Pengaruh Leverage, Ukuran Perusahaan, Pertumbuhan Perusahaan, Dan Profitabilitas Terhadap Nilai Perusahaan Pada Perusahaan Properti.

21. Terhadap Nilai Perusahaan. Akuntabilitas: Jurnal Ilmu Akuntansi Volume 10 (2), Oktober 2017 PIssn: 1979-858x; E-Issn: 2461-1190 Page $333-$ 348

22. Vernimmen, P., Quiry, P., Dallocchio, M., Yann, L. F., and Salvi, A. (2005).Corporate finance theory and practice. Scotland: John Wiley \& Sons, Ltd. 